\title{
Screening of heavy metal containing waste types for use as raw material in Arctic clay- based bricks
}

Belmonte, Louise Josefine; Ottosen, Lisbeth M.; Kirkelund, Gunvor Marie; Jensen, Pernille Erland; Vestbø, Andreas Peter

\section{Published in:}

Environmental Science and Pollution Research

Link to article, DOI:

$10.1007 / \mathrm{s} 11356-016-8040-\mathrm{z}$

Publication date:

2018

Document Version

Peer reviewed version

Link back to DTU Orbit

Citation (APA):

Belmonte, L. J., Ottosen, L. M., Kirkelund, G. M., Jensen, P. E., \& Vestbø, A. P. (2018). Screening of heavy metal containing waste types for use as raw material in Arctic clay-based bricks. Environmental Science and Pollution Research, 25, 32831-32843. https://doi.org/10.1007/s11356-016-8040-z

\section{General rights}

Copyright and moral rights for the publications made accessible in the public portal are retained by the authors and/or other copyright owners and it is a condition of accessing publications that users recognise and abide by the legal requirements associated with these rights.

- Users may download and print one copy of any publication from the public portal for the purpose of private study or research.

- You may not further distribute the material or use it for any profit-making activity or commercial gain

- You may freely distribute the URL identifying the publication in the public portal 


\section{Screening of heavy metal containing waste types for use as raw material in Arctic clay-based bricks}

Belmonte, Louise Josefine ${ }^{\mathrm{a},}$, Ottosen, Lisbeth M. ${ }^{a}$, Kirkelund, Gunvor Marie $^{\mathrm{a} *}$, Jensen, Pernille Erland ${ }^{\mathrm{a}}$ and Vestbø, Andreas Peter ${ }^{b}$

${ }^{a}$ Arctic Technology Centre, DTU Civil Engineering, Technical University of Denmark, 2800 Kgs. Lyngby, Denmark. ${ }^{b}$ Danish Technological Institute, 2630 Taastrup, Denmark * corresponding author. E-mail address: gunki@byg.dtu.dk (G.M. Kirkelund).

\section{Abstract}

In the vulnerable Arctic environment, the impact of especially hazardous wastes can have severe consequences and the reduction and safe handling of these waste types are therefore an important issue. In this study, two groups of heavy metal containing particulate waste materials, municipal solid waste incineration (MSWI) fly and bottom ashes and mine tailings (i.e. residues from the mineral resource industry) from Greenland were screened in order to determine their suitability as secondary resources in clay-based brick production. Small clay discs, containing $20 \%$ or $40 \%$ of the different particulate waste materials, were fired and material properties and heavy metal leaching tests were conducted before and after firing. Remediation techniques (washing in distilled water and electrodialytical treatment) applied to the fly ash reduced leaching before firing. The mine tailings and bottom ash brick discs obtained satisfactory densities $\left(1669-2007 \mathrm{~kg} / \mathrm{m}^{3}\right)$ and open porosities (27.9-39.9 \%). In contrast, the fly ash brick discs had low densities $\left(1313-1578 \mathrm{~kg} / \mathrm{m}^{3}\right)$ and high open porosities (42.1-51.5 \%). However, leaching tests on crushed brick discs revealed that heavy metals generally became more available after firing for all the investigated materials and that further optimisation is therefore necessary prior to incorporation in bricks.

Keywords: MSWI fly ash, MSWI bottom ash, mine tailings, clay-based ceramics, heavy metals, Arctic, Greenland. 


\section{Introduction}

Clay-based ceramics, such as bricks, are heterogeneous materials, which can incorporate raw materials of wide ranging compositions, without impairing their technical properties (Dondi et al., 1997; Segadães et al., 2005; Torres et al., 2009; Zhang, 2013). Due to this ability, bricks have become a popular material in waste management research worldwide and several studies have demonstrated that clay-based bricks and tiles can successfully accommodate waste types, such as incineration ashes, mine tailings and dredged harbour sediments (Chen et al., 2011; Kasuriya et al., 2008; Mezencevova et al., 2012; Roy et al., 2007; Zhang et al., 2011). The benefits of waste addition in bricks, which are most often mentioned in the literature, are: 1 ) conservation of natural resources, e.g. by replacing natural clay with waste; 2 ) improved technical properties of the final product, e.g. improved mechanical strength of the produced bricks; 3) lowering of energy consumption in production, i.e. by lowering the firing temperature; 4) cost reductions on the final product, e.g. due to lower costs on raw materials and 5) solving disposal problems and protecting the environment.

In the vulnerable Arctic environment, the impact of especially hazardous wastes can have severe consequences (Lemly, 1994; Moiseenko, 1999; Poland et al., 2003; Ramirez-Llodra et al., 2015; Rylander et al., 2011) and the reduction and safe handling of these waste types are therefore an important issue in the Arctic nations. Although bricks are a well-suited building material for cold climates (Brick Industry Association, 2006), the Arctic region does not have a strong tradition for masonry structures in comparison to other parts of the world. In Greenland, for example, bricks are neither produced locally nor frequently applied for construction purposes. In many parts of the Arctic, construction materials have to be imported and often transported over long distances, which makes them costly. It is therefore important to investigate the potential for local building material production in these areas (Doherty, 1996). Recent studies have established that deposits of marine glaciogene clay, which are found throughout the former glaciated areas of the northern hemisphere, are suitable for brick production(Belmonte, 2015; Bertelsen et al., 2015). On the basis of this it is interesting to test whether bricks produced locally in the Arctic could also help to solve issues regarding waste handling and disposal by incorporating these waste materials and thus turning them into a secondary resource. 
In this paper, a screening of different MSWI ashes and mine tailings from Greenland was conducted in order to determine their potential suitability for incorporation in the production of clay-based bricks. Furthermore, MSWI fly ash which had been pre-treated by either an electrodialytic process or by a washing process in order to remove salts and directly mobile fractions of heavy metals, was included with the purpose of studying the effects of these treatments on the leaching behaviour.

The main residues produced by modern MSWI plants are bottom ash and flue gas cleaning residues such as fly ash (Hjelmar et al., 2011). Bottom ashes are heterogeneous mixtures of ash, metals and other noncombustible materials such as ceramics and glass and typically have grain sizes in the range from 0.06 $60 \mathrm{~mm}$ (Hjelmar et al., 2011). Fly ashes consist of the fine particulate matter, which are entrained in the flue gas and typically have grain sizes in the range of 0.002-2 mm (Hjelmar et al., 2011). The chemical compositions of MSWI bottom and fly ashes vary and depend on the materials being incinerated and the type of incinerator. The ashes can contain hazardous substances (e.g. defined according to (European Parliament and the council of the European Union, 2008)) and their use as secondary raw materials might therefore be excluded or restricted according to national legislation. Several researchers have, however, investigated and successfully incorporated MSWI ashes in clay-based ceramics (Kasuriya et al., 2008; Rambaldi et al., 2010; Zhang et al., 2011, 2007). In the mentioned studies, the ashes replaced between 2-60\% (by weight) of clay or sand and properties such as reduced leaching of heavy metals after firing (Rambaldi et al., 2010; Zhang et al., 2011, 2007) and enhanced densification (Kasuriya et al., 2008) were reported for the produced ceramics.

Due to the scarce and geographically wide-spread population in the arctic areas, municipal solid wastes are traditionally handled by dumping at open disposal sites and/or uncontrolled incineration (Poland et al., 2003). This was also common practice in Greenland before the 1990's (Eisted and Christensen, 2011; Kirkelund et al., 2012), however, increased awareness of the environmental impact has since led to the introduction of a waste strategy and several small municipal solid waste incineration (MSWI) plants. The incineration plants have simple flue gas cleaning systems by which fly ashes are collected by cyclones and/or electrostatic filters. The fly ashes are subsequently exported at high costs, while bottom ashes 
are dumped at local unlined disposal sites. The present handling of both ash types calls for a more sustainable solution, which might be valorisation as secondary raw material.

Mine tailings worldwide often present major economic and environmental challenges to both the mining companies and the local community (Lorber and Antrekowitsch, 2011; Ramirez-Llodra et al., 2015; Reid et al., 2009; Roy et al., 2007). They are traditionally disposed in large subaerial (or underground) facilities or in subaqueous environments, e.g. lakes or marine water. Due to serious environmental hazards, such as heavy metal pollution, the tailings disposals often need continuous surveillance even after the mining operations have terminated (Elberling et al., 2002; Ramirez-Llodra et al., 2015). Several authors have investigated the potential for using residues from the mineral resource industry as secondary raw materials for the production of clay-based ceramics (Chen et al., 2011; Menezes et al., 2005; Roy et al., 2007; Segadães et al., 2005; Torres et al., 2009). Benefits such as increased durability (Torres et al., 2009), reduced firing temperature (Segadães et al., 2005) and lowered total cost (Roy et al., 2007) were reported for the produced ceramics. The Arctic area contains several mining operations and has already experienced severe environmental problems relating to tailings (Askaer et al., 2008; Poland et al., 2003) Up until this date, only a few mines have been in operation in Greenland, but serious environmental problems relating to the tailings from some of these mines have also been experienced here (Johansen and Asmund, 2001). Use of the mine tailings in clay-based bricks might offer an environmentally better alternative to disposal, which is addressed in this paper.

\section{Materials and methods}

\subsection{Raw materials}

\subsubsection{Marine clay}

Marine glaciogene clays are known from numerous localities throughout the Arctic and former glaciated areas of the Northern hemisphere (Belmonte, 2015; Gillott, 1979; Locat and St-Gelais, 2014; Locat et al., 1984; Ramesh and D’Anglejan, 1995; Roaldset, 1972; Rosenqvist, 1975). Approximately $150 \mathrm{~kg}$ of marine clay from the town of Ilulissat, West Greenland, was sampled from a depth interval of $20-100 \mathrm{~cm}$ below surface. The material was stored in closed containers at room temperature until use. 


\subsubsection{Incineration residues}

Municipal solid waste incineration (MSWI) plants exist in the six largest towns in Greenland (Eisted and Christensen, 2011; Kirkelund et al., 2013). The combustible fractions from residential waste, commercial waste and construction waste are incinerated and the bottom ash is landfilled at disposal sites without control of leachate and gas (Eisted and Christensen, 2011). The current annual production of bottom ash and fly ash in Greenland is estimated to be 6000 tonnes and 200 tonnes, respectively (Eisted and Christensen, 2011). The samples used in this study were collected from the MSWI plant in the town of Sisimiut, West Greenland. Both the bottom ash and fly ash were collected as fresh samples from the incineration plant and stored at room temperature until use.

\subsubsection{Mine tailings}

Mine tailings from two South Greenlandic sites, the Nalunaq Gold Mine and the Tanbreez Mining Greenland A/S project, were investigated.

The Nalunaq Gold Mine is currently not in operation, but was at the time of sampling (summer 2012) operated by Angel Mining Plc. The Nalunaq gold mineralisation is classified as a mesothermal vein-type gold deposit hosted in metavolcanic rocks (Secher et al., 2008) and the surrounding region is characterised as a gold province with several promising occurrences (Steenfelt, 2000; Stendal and Secher, 2002). The ore, which consists of a gold-bearing quartz vein (known as the main vein) and proximal hydrothermally altered dolerites and amphibolites (Schlatter and Olsen, 2011), was crushed, milled and treated by cyanide leaching in an extraction plant on-site. The tailings slurry was subjected to detoxification using the Inco method (Lewis, 1984) and subsequently pumped into a tailings dam located in previously exploited levels of the mine. At the time of sampling, the estimated tailings production was $50,000-70,000$ tonnes per year. In this study, tailings were obtained from the discharge of the detoxification tank before going into the tailings dam. The sampled slurry contained $20-22 \%$ solids, which were left to settle before the excess water was decanted. 
The Tanbreez Mining Greenland A/S project currently holds an exploration licence in the llimaussaq intrusion complex. The project mainly focuses on extracting rare earth elements from a laminated karkortokite, which consists of separate layers of feldspar, eudialyte and mafic minerals such as arfvedsonite and aegirine (Sorensen, 2001). The on-site ore processing will involve dry crushing followed by magnetic separation. The magnetic separation will produce three concentrates, an eudialyte, a feldspar and a mafic mineral concentrate. Furthermore, a fine-grained residue, representing bulk rock, will also originate from the ore crushing. The mafic mineral concentrate and fine grained residue are currently considered as tailings, which are planned to be disposed on-site. It is expected that the production will result in 230,000 tonnes of tailings per year, whereof the mafic concentrate will constitute approximately 180,000 tonnes and the fine grained residue will constitute 50,000 tonnes. In this study, both the mafic concentrate (Tanbreez mafic) and the fine-grained bulk residue (Tanbreez fines) were used.

\subsection{Methods}

\subsubsection{Initial treatments of the raw materials}

Large fragments (>1 mm) in both the marine clay and the bottom ash were removed before further use, by wet and dry sieving respectively. The fly ash was subjected to two different remediation treatments: 1) a portion was washed with distilled water in a $45 \mu \mathrm{m}$ filter using a liquid to solid (L/S) ratio of approximately 10 in order to remove salts 2) a second portion was subjected to electrodialytical remediation for removal of heavy metals and salts (Kirkelund et al, 2010). In the following the three fly ash batches are named 1) fly ash (untreated), 2) fly ash (washed) and 3) fly ash (ED).

The Nalunaq tailings were washed in a $45 \mu \mathrm{m}$ filter with distilled water using a $\mathrm{L} / \mathrm{S}$ ratio of 10 in order to remove potential soluble cyanide. All materials were dried at $105^{\circ} \mathrm{C}$ for 48 hours.

\subsubsection{Characterisation of samples}

The particle size distributions were determined on a Malvern Mastersizer 2000 laser diffractometer. All samples, except the marine clay, were analysed in dry state. Due to agglomeration of clay sized particles, the marine clay sample was instead pre-dispersed in $20 \mathrm{~mL} 0,005 \mathrm{M} \mathrm{Na}_{4} \mathrm{P}_{2} \mathrm{O}_{7}$ and analysed by 
wet dispersion in deionized water. For all samples, the Mie theory was applied in the calculations of the particle size distribution using a real refractive index of 1.5 and an imaginary refractive index of 0.1. Major-element analyses were determined using energy dispersive X-ray fluorescence (ED-XRF) on pressed powder tablets prepared from crushed samples. The loss on ignition (LOI) was based on weight loss between $105^{\circ} \mathrm{C}$ and $1000^{\circ} \mathrm{C}$ and was measured after heating at $1000^{\circ} \mathrm{C}$ for 2 hours. The qualitative mineralogy was analysed by X-ray powder diffraction (XRPD) on a X'Pert PRO diffractometer, using Nifiltered $\mathrm{Cu} \mathrm{K}_{\alpha}$ radiation generated at $45 \mathrm{kV}$ and $40 \mathrm{~mA}$.

Leaching tests were conducted on all samples, except the marine clay, according to the principles stated in (DS/EN 12457-1, 2002). $40.0 \mathrm{~g}$ of material was placed in a bottle and $80.0 \mathrm{~mL}$ distilled water was added in order to achieve a liquid to solid ratio of 2 . The suspension was agitated for 24 hours. Afterwards, the suspension settled for 15 minutes and was filtrated through a $45 \mu \mathrm{m}$ filter. The resulting eluates were measured by inductively coupled plasma optical emission spectrometry (ICP-OES) for As, $\mathrm{Ba}, \mathrm{Cd}, \mathrm{Cr}, \mathrm{Cu}, \mathrm{Mn}, \mathrm{Na}, \mathrm{Ni}, \mathrm{Pb}$, and $\mathrm{Zn}$.

The total heavy metal concentrations ( $\mathrm{As}, \mathrm{Cd}, \mathrm{Cr}, \mathrm{Cu}, \mathrm{Ni}, \mathrm{Pb}$ and $\mathrm{Zn}$ ) of ashes and tailings were measured by ICP-OES after pre-treatment according to Danish standard (DS 259, 2003), where $1.0 \mathrm{~g}$ of dry sample and $20.0 \mathrm{~mL} 7.3 \mathrm{M} \mathrm{HNO}_{3}$ were heated at $200 \mathrm{kPa}\left(120^{\circ} \mathrm{C}\right)$ for $30 \mathrm{~min}$. The liquid was separated from the solid particles by vacuum through a $0.45 \mu \mathrm{m}$ filter and diluted to $100 \mathrm{~mL}$. Samples of the unwashed and washed Nalunaq tailings were analysed for total cyanide according to (DS/ISO 17380, 2005).

\subsubsection{Production and test of brick discs}

Torres et al. (2009) demonstrated that initial tests conducted on small scale brick discs were a useful screening tool for selecting the best compositions of mixtures of clay and waste. In this paper a similar approach was adopted, using the same disc size, moisture content, dry-pressing load and maximum firing temperature as described by Torres et al. (2009). Brick discs were prepared from different mixtures of samples (see Table 1). 
[Table 1 here]

Table 1. Overview of disc mixtures with amounts given in wt \%.

The Atterberg limits (liquid and plastic limits) were determined, in order to investigate the plastic properties of the mixtures. The liquid limits $\left(w_{L}\right)$ were measured using the Casagrande method (DIN $18122-1,1997)$ and plastic limits $\left(w_{P}\right)$ were determined by the rolling method (ISO/TS 17892-12, 2004). For the preparation of the discs, $2 \mathrm{~g}$ of the mixture was placed in a small vial and distilled water was added in order to obtain a moisture content of approximately $15 \%$. The vials were sealed and the mixtures were left overnight to absorb the moisture. Discs were produced by uniaxial compression in a purpose-built disc mould placed in a manually operated Stenhøj hydraulic press. A maximum load of $14.81 \pm 0.04 \mathrm{kN}$ (equivalent to the pressure of $47 \mathrm{MPa}$ used by (Torres et al., 2009)) was applied. The initial weights, diameters and heights of the discs were measured by use of a laboratory scale and a precision micrometer scale gauge. The discs were dried at $105^{\circ} \mathrm{C}$ for 24 hours before the weights, diameters and heights were measured again. The discs were fired at $1000^{\circ} \mathrm{C}$ for 1 hour in a Vecstar laboratory Furnace, using an average heating and cooling rate of $6.8^{\circ} / \mathrm{min} \pm 2.5^{\circ} / \mathrm{min}$ and $1.9^{\circ} / \mathrm{min} \pm$ $0.5^{\circ} / \mathrm{min}$, respectively. After cooling to approximately $200^{\circ} \mathrm{C}$, the discs were removed from the furnace and placed in a desiccator in order to cool to room temperature before weights, diameters and heights were measured again.

A total of seven discs were produced from each mixture. Three were used for measurements of open porosity, dry density and vacuum water absorption, three were used for leaching tests and one disc was used for mineralogy.

The open porosity, dry density and vacuum water absorption were determined following the principles of procedure Ti-B-25 by the Danish Technological Institute (Danish Technological Institute, 1983): The discs were dried at $105^{\circ} \mathrm{C}$, cooled to room temperature in a desiccator and weighed $\left(\mathrm{m}_{\mathrm{dry}}\right)$. The dried discs were then placed in a desiccator under vacuum for approximately 3 hours. After 3 hours, distilled water at room temperature was led into the desiccator, so that the discs were completely submerged. Vacuum was maintained for this condition for 1 hour. Hereafter, air was let into the desiccator and the submerged discs were left at atmospheric pressure overnight. The water saturated discs were weighed 
in water $\left(m_{s w}\right)$ and in air after wiping excess water of the surface $\left(m_{s a}\right)$. The different parameters were calculated as described in the following:

Open porosity $=\frac{\mathrm{m}_{\mathrm{sa}}-\mathrm{m}_{\mathrm{dry}}}{\mathrm{m}_{\mathrm{sa}}-\mathrm{m}_{\mathrm{sw}}} \cdot 100 \%$

Dry density $=\frac{m_{d r y} \cdot \rho_{\mathrm{w}}}{m_{\mathrm{sa}}-\mathrm{m}_{\mathrm{sw}}} \cdot 100 \%$, where $\rho_{\mathrm{w}}$ is the density of water at room temperature.

Vacuum water absorption $=\frac{m_{s a}-m_{d r y}}{m_{d r y}} \cdot 100 \%$

Leaching tests on crushed discs, which would represent waste bricks and worst-case scenario leaching, were conducted according to the principles stated in DS/EN 12457-1 (2002). Three discs from each mixture were crushed and homogenised in order to obtain enough material (approximately 5-6 g) for one leaching test. The crushed discs were placed in a bottle and distilled water was added to achieve a liquid to solid ratio of 2 . The suspension was agitated for 24 hours. Afterwards, the suspension settled for 15 minutes and was filtrated through a $45 \mu \mathrm{m}$ filter. The resulting eluates were measured by ICP-OES for As, Ba, Cd, Cr, Cu, Mn, $\mathrm{Na}, \mathrm{Ni}, \mathrm{Pb}$, and $\mathrm{Zn}$.

The qualitative mineralogy of the crushed discs was investigated by XRPD using the same equipment and operating conditions as described in section 2.2.2.

\section{Results}

The particle size distributions of all samples are presented in Figure 1. The fly ash (washed and ED) and the Tanbreez fines had similar particle size distributions as the marine clay. In comparison, the fly ash (untreated) contained a larger volume \% of fine particles; whereas the bottom ash, Nalunaq tailings and Tanbreez mafic were dominated by coarser particles.

[Figure 1 here]

Figure 1. The particle size distributions of the investigated raw samples.

[Table 2 here]

Table 2. The major element distribution and loss on ignition (LOI) given as wt $\%$ of the corresponding oxides in the investigated raw samples. 
The major element composition and LOI data are presented in Table 2. The marine clay, Nalunaq and Tanbreez tailings were dominated by $\mathrm{SiO}_{2}$. Also $\mathrm{Al}_{2} \mathrm{O}_{3}$ was a major component, however for Nalunaq and Tanbreez mafic, $\mathrm{CaO}$ and $\mathrm{Fe}_{2} \mathrm{O}_{3} \mathrm{~T}$ (i.e. total $\mathrm{Fe}_{2} \mathrm{O}_{3}$ ), respectively, were more dominant than $\mathrm{Al}_{2} \mathrm{O}_{3}$. The fly ashes and bottom ash were dominated by $\mathrm{CaO}$, although the bottom ash also contained a large fraction of $\mathrm{SiO}_{2}$. The fly ashes had large LOI values, ranging from 30-43 weight $\%$. The amounts of the fluxing oxides, $\mathrm{Na}_{2} \mathrm{O}, \mathrm{K}_{2} \mathrm{O}$, which lower the melting temperature during firing (Worrall, 1975) ranged from 1.5123.11 wt $\%$ with the highest values found for the fly ash (untreated) and Tanbreez fines.

The total cyanide measured for the washed and unwashed Nalunaq samples were very similar with values of $26 \mathrm{mg} / \mathrm{kg}$ and $18 \mathrm{mg} / \mathrm{kg}$, respectively. In comparison, a level of $50 \mathrm{mg} / \mathrm{l}$ weak acid dissociable (WAD) cyanide (which constitutes parts of the total cyanide concentration) has been used as regulatory guideline for tailings slurries in open disposals in the United States and Australia. This level is acceptable for animals, which come into contact with the tailings (Lottermoser, 2007). The initial washing did not contribute to any reduction of cyanide, and could therefore have been emitted.

The resulting XRPD diffractograms of the raw materials and discs are shown in Figure 2 and 3 , respectively.

[Figure 2 here]

Figure 2. XRPD diffractograms of the raw materials. Only prominent peaks are listed. In case of peak overlap, only the dominant phase is indicated.

\section{[Figure 3 here]}

Figure 3. XRPD diffractograms of the discs. Only prominent peaks are listed. In case of peak overlap, only the dominant phase is indicated.

As expected the marine clay had the dominant influence on the mineralogical composition of the discs, due to its larger weight fraction, and all discs contained quartz and feldspar (albite and anorthite). 
Chlorite and mica (biotite and illite) peaks were not observed in the disc diffractograms, indicating that these phases were decomposed during the firing. For the fly ash discs, melilite, sodalite and pyroxene (diopside) peaks were seen to appear after firing, whereas halite $(\mathrm{NaCl})$, sylvite $(\mathrm{KCl})$ and calcite $\left(\mathrm{CaCO}_{3}\right)$ peaks were not observed after firing. The Tanbreez mafic and fines contained several Na-rich mineral phases, such as aegirine (Na-pyroxene), arfvedsonite (Na-amphibole), aenigmatite and sodalite. The diffractograms of the 7B and $8 B$ discs (40\% fines and mafic) showed markedly reduced quartz peaks compared with the other diffractograms, possibly indicating that quartz is dissolved in the glass phase.

The total metal concentrations and leaching results from the investigated samples are shown in Table 3. There are currently no Greenlandic regulations or guidelines for incorporating waste in construction materials or for using it for construction purposes. The Danish (or European) regulations, which are often adapted in Greenland when local guidelines are lacking, only include regulations for reuse of waste for construction purposes, i.e. in roads, dams, foundations etc. (Danish Ministry of the Environment (Miljøministeriet), 2015) and does not apply to hazardous materials (classified according to (Danish Ministry of the Environment (Miljøministeriet), 2012) and (European Parliament and the council of the European Union, 2008)). Although, the investigated waste materials and crushed discs might classify as hazardous, it is still informative to compare with the Danish regulation values as a first approximation. The categories 1, 2 and 3 of the Danish regulation (Danish Ministry of the Environment (Miljøministeriet), 2015) are controlled by the total and leached concentrations and the values shown in Table 3 represent maximum allowed values in each category. A material as a whole is categorised according to the highest category obtained for the individual elements, ions or compounds.

\section{[Table 3 here]}

Table 3. Total metal concentrations of the raw samples and leaching properties $(\mathrm{L} / \mathrm{S}=2)$ of the raw samples. Values are compared to Danish regulatory values (category 1-3) for construction purposes (Danish Ministry of the Environment (Miljøministeriet), 2015). 
When comparing the leaching tests for the investigated waste samples in this study with the regulation, it was apparent that all the fly ashes and the bottom ash classified outside category due to high leaching values of e.g. As, $\mathrm{Cd}, \mathrm{Cr}$ and $\mathrm{Pb}$, and were not suitable for use according to the regulation. The Nalunaq and Tanbreez mafic tailings both classified as category 3, due to high leaching values of As for Nalunaq and $\mathrm{Pb}$ and $\mathrm{Zn}$ for Tanbreez mafic. Most of the values for Tanbreez fines comply with category 1, however due to standard limitations it was not possible to determine the exact total concentration of $\mathrm{Cd}$ and leaching values for $\mathrm{As}, \mathrm{Cd}, \mathrm{Cr}, \mathrm{Ni}$ and $\mathrm{Pb}$ and it was therefore not possible to determine, which of the three categories it belonged to. Non-hazardous waste bricks are also covered by the Danish regulation for reuse of waste for construction purposes.

\section{[Table 4 here]}

Table 4. Leaching properties ( $\mathrm{L} / \mathrm{S}=2$ ) of the disc samples and mobility of the metals in the dics normalized to the mobility of the corresponding waste material (- at least of the leaching values were below the detection limit)

However, according to the leaching tests all crushed discs (Table 4), which represent waste bricks, classified outside category. Although the discs only contained $20 \%$ and $40 \%$ of the waste materials, leaching values for some elements were observed to increase in comparison to the raw samples. Particularly, As and $\mathrm{Cr}$ became more available to leaching after firing. This is seen by an evaluation of the actual influence of the thermal treatment on the possible incorporation in the clay dics can be evaluated by comparing the leaching of the dics and the leaching of the materials, as proposed by Karius and Hamer (2001). The heavy metal mobility from the disc (calculated by the leaching (table 4) and total concentrations (Table 3) were normalised by the heavy metal mobility of the materials itself (calculated by the leaching and total concentrations (Table 3) and these values are shown in Table 4.

The Atterberg limits (plastic and liquid limits) and the plasticity index are given in Table 5. 
Table 5. The plastic limit $\left(\mathrm{w}_{\mathrm{P}}\right)$, liquid limit $\left(\mathrm{w}_{\mathrm{L}}\right)$, and plasticity index $\left(\mathrm{PI}\right.$, calculated as $\left.\mathrm{W}_{\mathrm{L}}-\mathrm{W}_{\mathrm{P}}\right)$ of the disc mixtures (before firing).

The plastic limit $\left(w_{p}\right)$ of a mixture represent the lower boundary of plastic behaviour, i.e. the water content above which the mixture can be moulded and retain its shape. As the liquid limit $\left(w_{L}\right)$ is exceeded the mixtures will no longer be coherent and lose their plasticity. The plasticity index (PI) is included to evaluate the span between the plastic and liquid limit. All mixtures had low plasticity indices, which indicated that their 'moulding range' was very limited. The fly ash and bottom ash mixtures generally had both plastic and liquid limits in the same range or above that of the pure clay (mixture 1), whereas the tailings mixtures generally had lower limits compared to the pure clay.

The initial water content of the discs before firing and the shrinkage, appearance, water absorption, open porosity and dry density after firing are shown in Table 6. Some discs had negative firing shrinkages, i.e. they expanded slightly during firing without their overall shape and coherency being affected. The open porosity increased with addition of fly ash and decreased with addition of bottom ash and mine tailings in comparison to the natural clay. The same trend was also observed for the water absorption.

[Table 6 here]

Table 6. The initial water content (before drying and firing), shrinkage, appearance, vacuum water absorption, open porosity and dry density of the discs.

\section{Discussion}

\subsection{Mixing and choice of forming process}

Based on a spotted appearance of the fired fly ash discs it was clear that the mixtures of clay and fly ashes had not been homogenised fully during mixing. For larger scale testing or production, the application of mechanical grinding or milling in the mixing process could potentially solve this problem. 
The low plasticity index $(<10)$ found for all tested raw samples indicate that their plastic range is very limited, which can present a problem in the forming process. In the case of the dry pressing method (which was used in this study) the plasticity is not important, but plays an important role in other forming methods, such as the extrusion or soft-mud methods (Brick Industry Association, 2006). The high plastic limits of the fly ashes compared to the other raw samples indicate that more water would be needed in order to obtain a mouldable mass. More water would, however, also increase the shrinkage and thereby the risk of developing cracks during firing.

\subsection{Physical properties and mineral chemistry of the discs}

The small negative firing shrinkage (expansion) observed for discs $3 \mathrm{~A}$ ( $20 \% \mathrm{fly}$ ash (washed)), 3B (40\% fly ash (washed)), 4A (20\% fly ash (ED)), 5A (20\% bottom ash) and 5B (40\% bottom ash) is most likely explained by bloating (Riley, 1951), a process that is utilized for the production of lightweigth expanded clay aggregates. At temperatures at or above the sintering temperature gas from decomposition of e.g. sulphate (from anhydrite) and carbonate (from calcite) could be trapped in the material and thus expand the discs.

The expansion is not observed for discs 4B (40\% fly ash ED), however, the above mentioned heterogeneities could account for this. The fly ash (untreated) likely contains less calcite compared to the other fly ashes and the bottom ash, based on its lower content of $\mathrm{CaO}$. This difference could also explain why the fly ash (untreated) discs do not show evidence of expansion. The Nalunaq discs, $6 \mathrm{~B}$, had negative firing shrinkages, whereas discs $6 \mathrm{~A}$, had positive firing shrinkages. Apparently, expansion therefore occurs for compositions containing more than $20 \%$ of the Nalunaq tailings. The presence of sulphides, which are associated with the Nalunaq ore (Schlatter and Olsen, 2011), could give rise to bloating effects as $\mathrm{SO}_{2}$ is liberated during firing (Riley, 1951). Discs $8 \mathrm{~A}$ and $8 \mathrm{~B}$ (20\% and $40 \%$ Tanbreez mafic, respectively) have some of the lowest observed open porosities and highest densities of all investigated disc types, indicating a high degree of sintering. The high degree of sintering is consistent with the high content of $\mathrm{Na}$ compounds, which can act as fluxing materials and aid vitrification at elevated temperatures (Bloodworth et al., 2007). Furthermore the observed reduction of the quartz 
peaks is also consistent with enhanced melt formation, i.e. vitrification. Interestingly the firing shrinkages of discs $8 \mathrm{~A}$ and $8 \mathrm{~B}$ seem to be lower than that of the clay, although the drying shrinkages are slightly higher. Dry densities of clay bricks, which are used in the building industry, have been reported to be in the range of $1610-2120 \mathrm{~kg} / \mathrm{m}^{3}$ (Dondi et al., 2004, 2000) and open porosities in the range of 18.8-39 vol \% (Dondi et al., 2004). In comparison to these values the fly ash discs generally have lower densities and higher porosities, whereas the clay, bottom ash and tailings discs are within the range. Because of the high open porosity and water absorption of the fly ash discs, it is likely that these will be less durable compared to the other disc types, due to e.g. spalling effects created by saline water mobility or freezing and thawing. The fly ash could possibly be utilised for lightweight bricks, which should not be in direct contact with water or exposed to outdoor climate.

\subsection{Leaching and total concentrations of heavy elements}

The increased leaching of heavy metals from the crushed discs compared to the samples is problematic. The change in mobility of each metal when the waste materials were incorporated in the disc in Table 4, reveals that As and $\mathrm{Cr}$ were mobilised by the thermal treatment (ratio $>1$ ). This has also been seen in another study when using contaminated harbour sediments in bricks (Karius and Hamer, 2001). The only exception of increased mobility if As and $\mathrm{Cr}$ were in the discs with raw fly ash. Alonso-Santurde et al. (2011) showed that $\mathrm{Cr}$ leaching is not dependent on the liquid to solid ratio when incorporating spent foundry sand in bricks. Volatile metals can be released during the firing process (Domínigues et al. 2012), which can result in a reduced mobility of these metals in the clay disc, but requires flue gas treatment after the firing, if to be used commercially. Rambaldi et al. (2010) found that a mixture containing 5\% untreated MSWI bottom ash, 40\% kaolinitic and ilitic clay, $25 \%$ Na-feldspar sand, $25 \% \mathrm{~K}-$ feldspar sand and $10 \%$ dolomite allowed for the formation of a silicatic matrix (at firing temperatures > $1100^{\circ} \mathrm{C}$ ), which could embed heavy metals (including As and $\mathrm{Cr}$ ) and thus effectively reduce leaching. Zhang et al. (2011) and Zhang et al. (2007) used MSWI fly ash in ceramic bricks and found that an optimal mixture of $20 \%$ fly ash, $60 \%$ red clay and $20 \%$ granular additives (described as gang sand and feldspar) fired at $950^{\circ} \mathrm{C}$ reduced leaching of $\mathrm{Cd}, \mathrm{Hg}, \mathrm{Pb}$ and $\mathrm{Zn}$ considerably. Although the XRF results for the red clay investigated by Zhang et al. (2011) are comparable to the XRF on the marine clay in this 
study, the materials used by Rambaldi et al. (2010) and Zhang et al. (2011) generally appear to be richer in Al compared to the materials used in this study. Furthermore, the feldspar additive used by Zhang et al. (2011) had a very high content of $\mathrm{K}$ and $\mathrm{Na}$ (fluxes), which would have contributed positively to lowering the sintering temperature. These very high $\mathrm{K}$ and $\mathrm{Na}$ values were not observed for any of the materials in this study or the study by Rambaldi et al. (2010). The leaching results from this study implies that an optimal silicatic matrix for containing the heavy metals has not been achieved for the given compositions at $1000^{\circ} \mathrm{C}$ and further optimization tests are therefore needed. Furthermore, for the crushed discs investigated in this study, it would appear that additional heavy metals have been mobilised during firing. An explanation for this could, for example, be the decomposition of sulphides, which (although not detected by XRD) could be present in small quantities and which often contain heavy metals (e.g. arsenopyrite, FeAsS).

\subsection{Remediation and upgrading}

The remediation techniques applied to the fly ash, e.g. washing and electrodialytical treatment, generally increased the total heavy metal concentrations of the solids, due to removal of soluble salts (as evidenced by $\mathrm{Na}$, Table 2). Heavy metal leaching was reduced for both the remediated ashes compared to the fly ash (untreated). The washing technique led to the highest reduction in leaching concentrations of all measured heavy metals, except $\mathrm{Cr}$, which was reduced more using the electrodialytical treatment. Neither of the fly ashes did, however, meet the requirements of the Danish regulations for reuse of waste for construction purposes (Danish Ministry of the Environment (Miljøministeriet), 2015). Depending on future regulatory values, the possibilities for remediating or upgrading all the studied waste materials should therefore be further investigated. A study by (Kirkelund et al., 2012) on the MSWI bottom ash from Sisimiut for use as an aggregate replacement in road construction, found that leaching of heavy metals, such as $\mathrm{Cu}$ and $\mathrm{Cr}$ were higher in the finest fractions. They concluded that the removal of these fractions by sieving would give a material which was less problematic and could be used for geotechnical purposes. A similar investigation should be attempted for the tailings and the influence of gravity separation could also be tested in order to remove e.g. sulphides. For all the investigated materials, the vitrification treatment (Colombo et al., 2003), where 
materials are fused at high temperatures in order to fix heavy metals in a glass matrix, could also be applied before incorporation.

\section{Conclusions}

The open porosities and densities of the tailings and bottom ash discs were acceptable for brick production. The fly ash discs, regardless of pre-treatment, generally had problematic properties, such as high open porosity, high water absorption and negative firing shrinkage compared to the other waste materials. These properties indicate that bricks incorporating the fly ashes could be less durable. Leaching values of all the tested discs generally revealed a higher mobility of As and $\mathrm{Cr}$ after firing, which was likely caused by decomposition of As and $\mathrm{Cr}$ containing phases, e.g. sulphides, during firing. This study concludes that producing fired clay bricks with the waste materials used as secondary resource at the firing temperature of $1000^{\circ} \mathrm{C}$ was not a solution for stabilisation and immobilisation of heavy metals such as e.g. As, $\mathrm{Cr}$ and $\mathrm{Pb}$. Although some discs obtained acceptable material properties, the problem of leaching needs to be taken into account by optimising the mixtures and the firing scheme.

\section{Acknowledgements}

This project was funded by the Government of Greenland, DTU Civil engineering and the Danish Agency for Science, Technology and Innovation. Louise Belmonte wishes to thank Angel Mining Plc. and Kurt Christensen for the opportunity to visit the Nalunaq Gold mine and for help and assistance during the stay and with collecting the tailings samples. The authors wish to thank Tanbreez Mining Greenland A/S for providing the Tanbreez tailings.

\section{References}

Alonso-Santurde, R., Andrés, A., Viguri, J.R., Raimondo, M., Guarini, G., Zanelli, C., Dondi, M., 2011. Technological behaviour and recycling potential of spent foundry sands. J. Environ. Manage. 92, 994-1002.

Askaer, L., Schmidt, L.B., Elberling, B., Asmund, G., Jónsdóttir, I.S., 2008. Environmental impact on an arctic soil-plant system resulting from metals released from coal mine waste in Svalbard $\left(78^{\circ} \mathrm{N}\right)$. 
Water. Air. Soil Pollut. 195, 99-114. doi:10.1007/s11270-008-9730-z

Belmonte, L.J., 2015. Use of Greenlandic resources for the production of bricks. Unpublished PhD thesis, Technical University of Denmark.

Bertelsen, I.M.G., Belmonte, L.J., Chen, W., Ottosen, L.M., 2015. Properties of bricks produced from Greenlandic marine sediments, in: Proceedings of the 23rd International Conference on Port and Ocean Engineering Under Arctic Conditions. Trondheim, Norway.

Bloodworth, A., Highley, D., Lusty, P., 2007. Brick Clay - Mineral Planning Factsheet, British Geological Survey.

Brick Industry Association, 2006. Manufacturing of brick - technical notes on brick construction 9. Reston, Virginia, USA.

Chen, Y., Zhang, Y., Chen, T., Zhao, Y., Bao, S., 2011. Preparation of eco-friendly construction bricks from hematite tailings. Constr. Build. Mater. 25, 2107-2111. doi:10.1016/j.conbuildmat.2010.11.025

Colombo, P., Brusatin, G., Bernardo, E., Scarinci, G., 2003. Inertization and reuse of waste materials by vitrification and fabrication of glass-based products. Curr. Opin. Solid State Mater. Sci. 7, 225-239. doi:10.1016/j.cossms.2003.08.002

Danish Ministry of the Environment (Miljøministeriet), 2015. BEK 1414: Bekendtgørelse om anvendelse af restprodukter og jord til bygge- og anlægsarbejder og om anvendelse af sorteret, uforurenet bygge- og anlægsaffald.

Danish Ministry of the Environment (Miljøministeriet), 2012. BEK 1309: Bekendtgørelse om affald.

Danish Technological Institute, 1983. Prøvningsmetode Bestemmelse af kapillær vandmætningsgrad Prøvningsmetode Bestemmelse af kapillær vandmætningsgrad.

DIN 18122-1, 1997. Baugrund, Untersuchung von Bodenproben - Zustandsgrenzen (Konsistenzgrenzen) Teil 1: Bestimmung der Fließ- und Ausrollgrenze.

Doherty, R., 1996. Social, economic and technical links between northern regions of Canada and Russia, in: Lyck, L., Boyko, V.I. (Eds.), Management, Technology and Human Resources Policy in the Artic (The North) : Proceedings of the NATO Advanced Research Workshop, Novosibirsk 1995. Kluwer Academic Publishers, pp. 19-30.

Domíngues, E., Dondi, M., Iglesias, C., 2012. Environmental suitability of ceramic raw materials: a 
geochemical approach to volatile emissions and leaching potentials. Environ. Earth Sci. 65, 517523.

Dondi, M., Marsigli, M., Fabbri, B., 1997. Recycling of Industrial and urban wastes in brick production : A review. Tile brick Int. 13, 218-225 and 302-315.

Dondi, M., Mazzanti, F., Principi, P., Raimondo, M., Zanarini, G., 2004. Thermal Conductivity of Clay Bricks. J. Mater. Civ. Eng. 16, 287-287. doi:10.1061/(ASCE)0899-1561(2004)16:3(287)

Dondi, M., Principi, P., Raimondo, M., Zanarini, G., 2000. Conduttività termica dei laterizi ottenuti con argille italiane (the thermal conductivity of bricks produced with Italian clays). L'industria dei Laterizi 65, 309-320.

DS 259, 2003. Determination of metals in water, sludge and sediments - General guidelines for determination by atomic absorption spectrophotometry in flame.

DS/EN 12457-1, 2002. Characterisation of waste - Leaching - Compliance test for leaching of granular waste materials and sludges - Part 1: One stage batch test at a liquid to solid ratio of $2 \mathrm{l} / \mathrm{kg}$ for materials with high solid content and with particle size below $4 \mathrm{~mm}$ (withou.

DS/ISO 17380, 2005. Soil quality - Determination of total cyanide and easily released cyanide Continous-flow analysis method.

Eisted, R., Christensen, T.H., 2011. Waste management in Greenland: current situation and challenges. Waste Manag. Res. 29, 1064-1070. doi:10.1177/0734242X10395421

Elberling, B., Asmund, G., Kunzendorf, H., Krogstad, E.J., 2002. Geochemical trends in metalcontaminated fiord sediments near a former lead-zinc mine in West Greenland. Appl. Geochemistry 17, 493-502. doi:10.1016/S0883-2927(01)00119-6

European Parliament and the council of the European Union, 2008. REGULATION (EC) no 1272/2008 on classification, labelling and packaging of substances and mixtures, amending and repealing Directives 67/548/EEC and 1999/45/EC, and amending Regulation (EC) No 1907/2006.

Gillott, J.E., 1979. Fabric, composition and properties of sensitive soils from Canada, Alaska and Norway. Eng. Geol. 14, 149-172. doi:10.1016/0013-7952(79)90082-6

Hjelmar, O., Johnson, A., Comans, R., 2011. Incineration: Solid Residues, in: Christensen, T.H. (Ed.), Solid Waste Technology \& Management. Wiley, pp. 430-462. doi:10.1002/97804706668883.ch29 
ISO/TS 17892-12, 2004. Geotechnical investigation and testing - Laboratory testing of soil - Part 12: Determination of Atterberg limits.

Johansen, P., Asmund, G., 2001. Pollution from Mining in Greenland - A Review, in: Olsen, H.K., Lorentzen, L., Rendal, O. (Eds.), Mining in the Arctic. Proceedingsof the Sixth International Symposium on Mining in the Arctic, Nuuk, Greenland, 28-31 May 2001. A.A.Balkema Publishers, pp. $29-35$.

Karius, V., Hamer, K., 2001. pH and grain-size variation in leaching tests with bricks made of harbour sediments compared to commercial bricks. Sci. Total Environ. 278, 73-85.

Kasuriya, S., Jiemsirilers, S., Thavorniti, P., 2008. Effect of MSW Incineration Bottom Ash in Clay Based Ceramics. Mater. Sci. Forum 569, 205-208. doi:10.4028/www.scientific.net/MSF.569.205

Kirklund, G.M., Jensen, P.E., Villumsen, A., Ottosen, L.M., 2010. Test of electrodialytic upgrading of MSWI APC residue in pilot scale: focus on reduced metal and salt leaching. J App. Electrohem. 40, 1049.1060. DOI 10.1007/s10800-009-0059-0.

Kirkelund, G.M., Jensen, P.E., Ottosen, L.M., 2013. Electrodialytic extraction of heavy metals from greenlandic MSWI Fly Ash as a function of remediation time and L/S ratio, in: ISCORD 2013: Planning for Sustainable Cold Regions - Proceedings of the 10th International Symposium on Cold Regions Development. Anchorage, Alaska, USA, pp. 87 - 96.

Kirkelund, G.M., Joergensen, A.S., Ingeman-Nielsen, T., Villumsen, A., 2012. Characterisation of MSWI bottom ash for potential use as subbase in Greenlandic road construction, in: 4th International Conference on Engineering for Waste and Biomass Valorisation (wasteeng12). Porto, Portugal, pp. $835-840$.

Lemly, A.D., 1994. Mining in northern Canada: Expanding the industry while protecting arctic fishes-A review. Ecotoxicol. Environ. Saf. 29, 229-242. doi:10.1016/0147-6513(94)90022-1

Lewis, A., 1984. New inco tech process attacks toxic cyanides. Eng. Min. J. Vol. 185, no. 7, pp. 52-54. July 1984.

Locat, J., Lefebvre, G., Ballivy, G., 1984. MINERALOGY, CHEMISTRY, AND PHYSICAL PROPERTIES INTERRELATIONSHIPS OF SOME SENSITIVE CLAYS FROM EASTERN CANADA. Can. Geotech. J. 21, $530-540$. 
Locat, J., St-Gelais, D., 2014. Nature of sensitive clays from Québec, in: L'Heureux, J.S., Locat, A., Leroueil, S., Demers, D., Locat, J. (Eds.), Landslides in Sensitive Clays : From Geosciences to Risk Management. Springer, pp. 25-37.

Lorber, K.E., Antrekowitsch, H., 2011. Disposal ponds and tailing dams. Waste Manag. Res. 29, 125-6. doi:10.1177/0734242X11398643

Lottermoser, B.G., 2007. Mine Wastes, Mine Wastes (Second Edition): Characterization, Treatment, Environmental Impacts. Springer Verlag, Berlin Heidelberg. doi:10.1007/978-3-540-48630-5

Menezes, R.R., Ferreira, H.S., Neves, G.A., Lira, H. de L., Ferreira, H.C., 2005. Use of granite sawing wastes in the production of ceramic bricks and tiles. J. Eur. Ceram. Soc. 25, 1149-1158. doi:10.1016/j.jeurceramsoc.2004.04.020

Mezencevova, A., Yeboah, N.N., Burns, S.E., Kahn, L.F., Kurtis, K.E., 2012. Utilization of Savannah Harbor river sediment as the primary raw material in production of fired brick. J. Environ. Manage. 113, 128-136. doi:10.1016/j.jenvman.2012.08.030

Moiseenko, T.I., 1999. The fate of metals in Arctic surface waters. Method for defining critical levels. Sci. Total Environ. 236, 19-39. doi:10.1016/S0048-9697(99)00280-6

Poland, J.S., Riddle, M.J., Zeeb, B.A., 2003. Contaminants in the Arctic and the Antarctic: a comparison of sources, impacts, and remediation options. Polar Rec. (Gr. Brit). 39, 369-383. doi:10.1017/S0032247403002985

Rambaldi, E., Esposito, L., Andreola, F., Barbieri, L., Lancellotti, I., Vassura, I., 2010. The recycling of MSWI bottom ash in silicate based ceramic. Ceram. Int. 36, 2469-2476. doi:10.1016/j.ceramint.2010.08.005

Ramesh, R., D'Anglejan, B., 1995. Mineralogy, chemistry and particle size interrelationships in some post-glacial marine deposits of the St. Lawrence Lowlands. J. Coast. Res. 11, 1167-1179.

Ramirez-Llodra, E., Trannum, H.C., Evenset, A., Levin, L.A., Andersson, M., Finne, T.E., Hilario, A., Flem, B., Christensen, G., Schaanning, M., Vanreusel, A., 2015. Submarine and deep-sea mine tailing placements: A review of current practices, environmental issues, natural analogs and knowledge gaps in Norway and internationally. Mar. Pollut. Bull. 97, 13-35.

doi:10.1016/j.marpolbul.2015.05.062 
Reid, C., Bécaert, V., Aubertin, M., Rosenbaum, R.K., Deschênes, L., 2009. Life cycle assessment of mine tailings management in Canada. J. Clean. Prod. 17, 471-479. doi:10.1016/j.jclepro.2008.08.014

Riley, C.M., 1951. Relation of chemical properties to the bloating of clays. J. Am. Ceram. Soc. 34, $121-$ 128.

Roaldset, E., 1972. Mineralogy and geochemistry of quaternary clays in the Numedal area, southern Norway. Nor. Geol. Tidsskr. 52, 335-369.

Rosenqvist, I.T., 1975. Origin and mineralogy glacial and interglacial clays of southern Norway. Clays Clay Miner. 23, 153-159. doi:10.1346/CCMN.1975.0230211

Roy, S., Adhikari, G.R., Gupta, R.N., 2007. Use of gold mill tailings in making bricks: a feasibility study. Waste Manag. Res. 25, 475-482. doi:10.1177/0734242X07076944

Rylander, C., Odland, J.Ø., Sandanger, T.M., 2011. Climate change and environmental impacts on maternal and newborn health with focus on Arctic populations. Glob. Health Action 4, 1-11. doi:10.3402/gha.v4i0.8452

Schlatter, D.M., Olsen, S.D., 2011. The Nalunaq gold mine: a reference sample collection and compilation and interpretation of geochemical data. Danmarks og Grønlands Geologiske Unders $\varnothing$ gelse Rapport. 2011/31.

Secher, K., Stendal, H., Stensgaard, B.M., 2008. The Nalunaq gold mine. Geol. Ore - Explor. Min. Greenl. $11,1-12$

Segadães, A.M., Carvalho, M.A., Acchar, W., 2005. Using marble and granite rejects to enhance the processing of clay products. Appl. Clay Sci. 30, 42-52. doi:10.1016/j.clay.2005.03.004

Sorensen, H., 2001. The llímaussaq alkaline complex, South Greenland: status of mineralogical research with new results. Geol. Greenl. Surv. Bull. 190, 7-23.

Steenfelt, A., 2000. Geochemical signatures of gold provinces in South Greenland. Appl. Earth Sci. 109, 14-22. doi:10.1179/aes.2000.109.1.14

Stendal, H., Secher, K., 2002. Gold mineralisation and gold potential in South Greenland. Geol. Ore Explor. Min. Greenl. 1, 1-12.

Torres, P., Fernandes, H.R., Olhero, S., Ferreira, J.M.F., 2009. Incorporation of wastes from granite rock cutting and polishing industries to produce roof tiles. J. Eur. Ceram. Soc. 29, 23-30. 
doi:10.1016/j.jeurceramsoc.2008.05.045

Zhang, H.Y., Zhao, Y.C., Qi, J.Y., 2011. Utilization of municipal solid waste incineration (MSWI) fly ash in ceramic brick: Product characterization and environmental toxicity. Waste Manag. 31, 331-341. doi:10.1016/j.wasman.2010.10.017

Zhang, H.Y., Zhao, Y.C., Qi, J.Y., 2007. Study on use of MSWI fly ash in ceramic tile. J. Hazard. Mater. 141, 106-114. doi:10.1016/j.jhazmat.2006.06.100

Zhang, L., 2013. Production of bricks from waste materials - A review. Constr. Build. Mater. doi:10.1016/j.conbuildmat.2013.05.043 


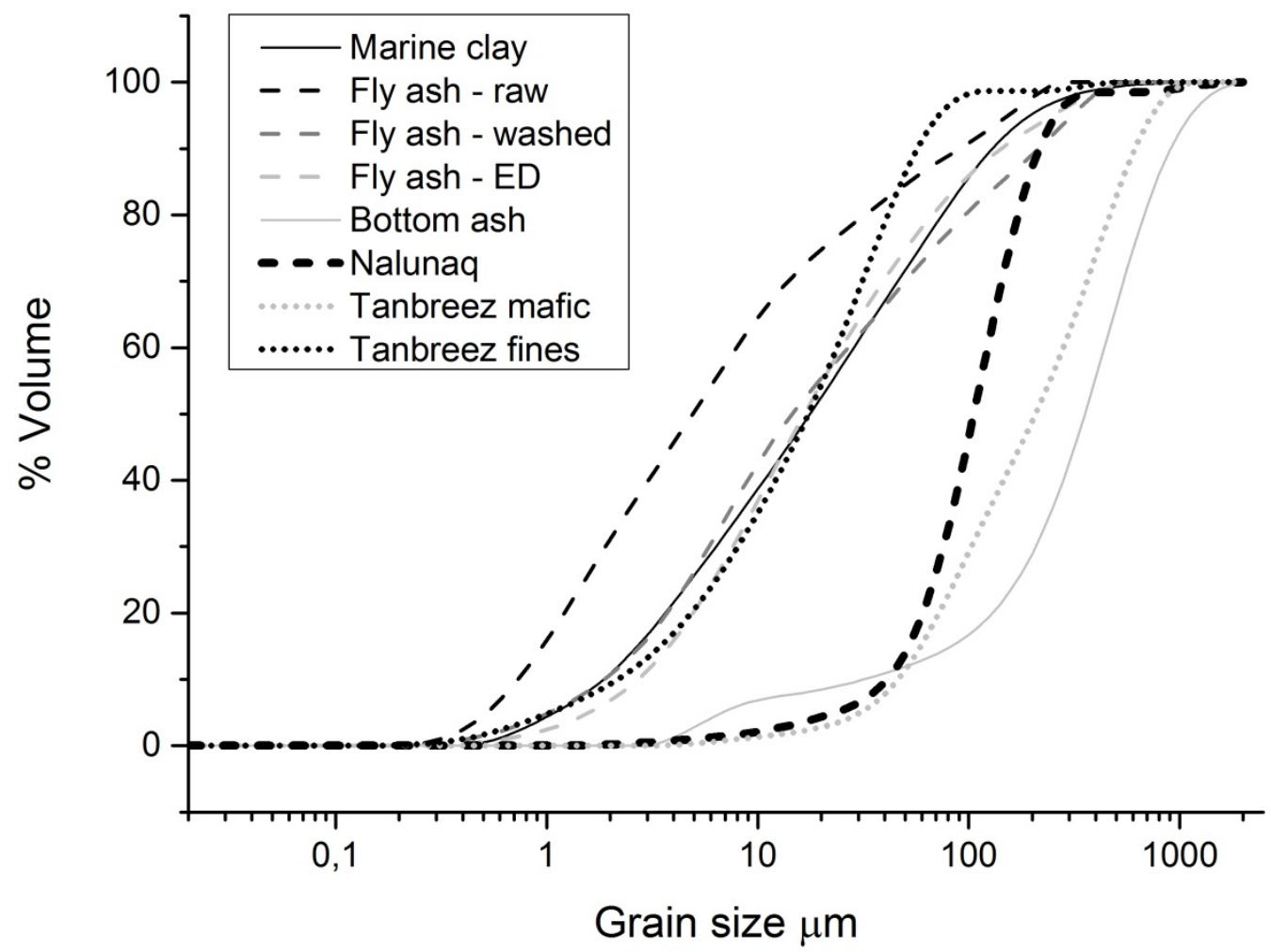

Figure 1. The particle size distributions of the investigated raw samples. 


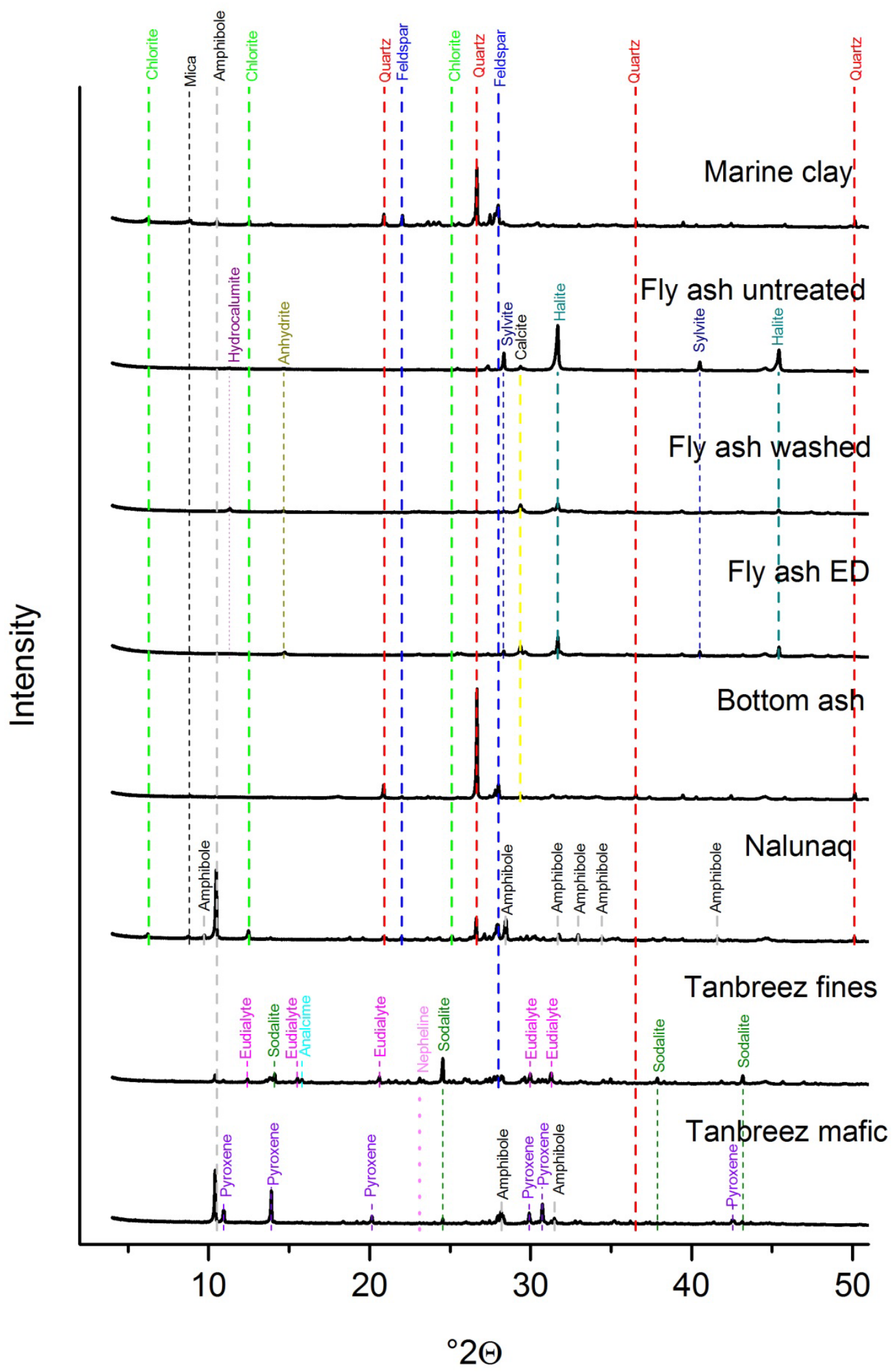

Figure 2. XRPD diffractograms of the raw materials. Only prominent peaks are listed. In case of peak overlap, only the dominant phase is indicated. 


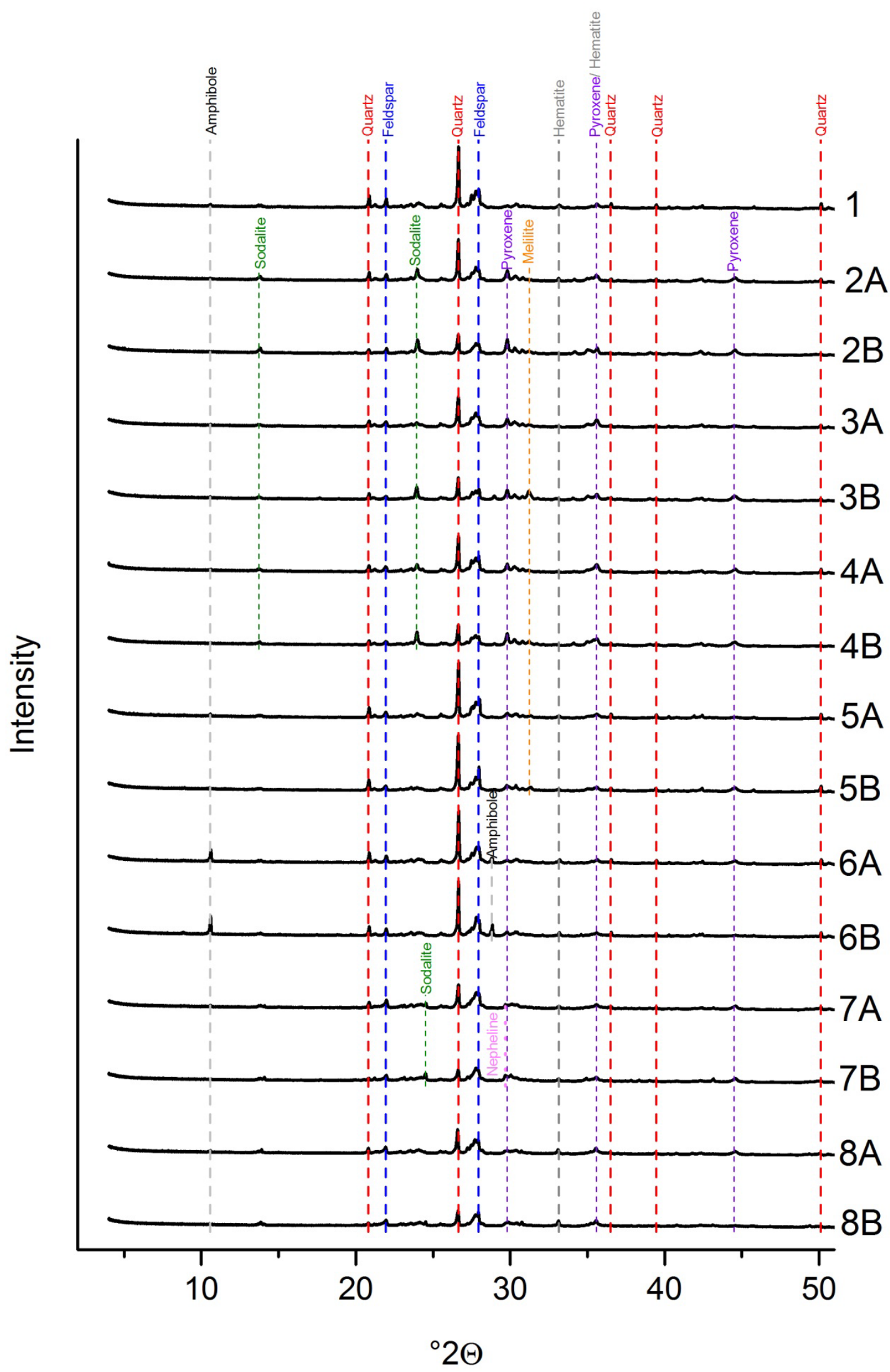

Figure 3. XRPD diffractograms of the discs. Only prominent peaks are listed. In case of peak overlap, only the dominant phase is indicated. 


\begin{tabular}{|c|c|c|c|c|c|c|c|c|}
\hline $\begin{array}{c}\text { Mixture } \\
\text { name }\end{array}$ & $\begin{array}{l}\text { Marine } \\
\text { clay (\%) }\end{array}$ & $\begin{array}{c}\text { Fly ash - } \\
\text { untreated (\%) }\end{array}$ & $\begin{array}{c}\text { Fly ash - } \\
\text { washed (\%) }\end{array}$ & $\begin{array}{c}\text { Fly ash - } \\
\text { ED (\%) }\end{array}$ & $\begin{array}{l}\text { Bottom } \\
\text { ash (\%) }\end{array}$ & $\begin{array}{c}\text { Nalunaq } \\
(\%)\end{array}$ & $\begin{array}{l}\text { Tanbreez } \\
\text { fines (\%) }\end{array}$ & $\begin{array}{l}\text { Tanbreez } \\
\text { mafic (\%) }\end{array}$ \\
\hline 1 & 100 & & & & & & & \\
\hline $2 \mathrm{~A}$ & 80 & 20 & & & & & & \\
\hline $2 B$ & 60 & 40 & & & & & & \\
\hline $3 A$ & 80 & & 20 & & & & & \\
\hline $3 B$ & 60 & & 40 & & & & & \\
\hline $4 \mathrm{~A}$ & 80 & & & 20 & & & & \\
\hline 4B & 60 & & & 40 & & & & \\
\hline $5 A$ & 80 & & & & 20 & & & \\
\hline $5 B$ & 60 & & & & 40 & & & \\
\hline $6 \mathrm{~A}$ & 80 & & & & & 20 & & \\
\hline $6 \mathrm{~B}$ & 60 & & & & & 40 & & \\
\hline $7 \mathrm{~A}$ & 80 & & & & & & 20 & \\
\hline $7 B$ & 60 & & & & & & 40 & \\
\hline $8 \mathrm{~A}$ & 80 & & & & & & & 20 \\
\hline $8 B$ & 60 & & & & & & & 40 \\
\hline
\end{tabular}

Table 1. Overview of disc mixtures with amounts given in wt \%. 


\begin{tabular}{lcccccccc} 
& $\begin{array}{c}\text { Marine } \\
\text { clay }\end{array}$ & $\begin{array}{c}\text { Fly ash - } \\
\text { untreated }\end{array}$ & $\begin{array}{c}\text { Fly ash - } \\
\text { washed }\end{array}$ & $\begin{array}{c}\text { Fly ash - } \\
\text { ED }\end{array}$ & $\begin{array}{c}\text { Bottom } \\
\text { ash }\end{array}$ & Nalunaq & $\begin{array}{c}\text { Tanbreez } \\
\text { fines }\end{array}$ & $\begin{array}{c}\text { Tanbreez } \\
\text { mafic }\end{array}$ \\
\hline $\mathrm{SiO}_{2}$ & 61.12 & 4.53 & 11.87 & 9.29 & 35.97 & 50.71 & 50.56 & 46.76 \\
$\mathrm{TiO}_{2}$ & 0.59 & 0.85 & 1.57 & 1.38 & 1.47 & 0.90 & 0.48 & 2.19 \\
$\mathrm{Al}_{2} \mathrm{O}_{3}$ & 14.52 & 2.96 & 6.92 & 5.27 & 7.35 & 13.03 & 16.69 & 7.43 \\
$\mathrm{Fe}_{2} \mathrm{O}_{3} \mathrm{~T}$ & 6.48 & 1.19 & 2.25 & 1.63 & 5.02 & 11.71 & 8.68 & 29.69 \\
$\mathrm{MnO}$ & 0.08 & 0.04 & 0.08 & 0.07 & 0.16 & 0.14 & 0.46 & 0.56 \\
$\mathrm{MgO}$ & 3.52 & 0.58 & 2.08 & 1.89 & 1.66 & 5.36 & 0.00 & 0.54 \\
$\mathrm{CaO}$ & 2.36 & 23.20 & 36.62 & 26.33 & 38.97 & 15.08 & 6.95 & 4.13 \\
$\mathrm{Na} 2 \mathrm{O}$ & 3.31 & 14.90 & 4.94 & 6.41 & 2.03 & 0.73 & 11.31 & 7.37 \\
$\mathrm{~K}_{2} \mathrm{O}$ & 2.81 & 8.21 & 1.64 & 3.74 & 1.06 & 0.78 & 2.53 & 1.32 \\
$\mathrm{P}_{2} \mathrm{O}_{5}$ & 0.12 & 0.55 & 1.92 & 1.90 & 1.73 & 0.00 & 0.00 & 0.00 \\
$\mathrm{LOI}$ & 5.09 & 43.01 & 30.10 & 42.11 & 4.58 & 1.58 & 2.33 & 0.01 \\
\hline
\end{tabular}

Table 2. The major element distribution and loss on ignition (LOI) given as wt \% of the corresponding oxides in the investigated raw samples. 


\section{Waste materials}

Fly ash untreated Fly ash washed

Fly ash ED

Bottom ash

Tanbreez fines

Tanbreez mafic Category 1 Category 2 Category 3

\begin{tabular}{|c|c|c|c|c|c|c|c|c|c|c|}
\hline \multicolumn{11}{|c|}{ Total concentration $(\mathrm{mg} / \mathrm{kg})$} \\
\hline As & $21 \pm 1$ & $228 \pm 4$ & $942 \pm 73$ & $10 \pm 2$ & $156 \pm 10$ & $<2$ & $<2$ & $0-20$ & $>20$ & $>20$ \\
\hline $\mathrm{Cd}$ & $93 \pm 3$ & $244 \pm 3$ & $827 \pm 25$ & $5 \pm 4$ & $<2$ & $<2$ & $<2$ & $0-0.5$ & $>0.5$ & $>0.5$ \\
\hline $\mathrm{Cr}$ & $70 \pm 2$ & $196 \pm 2$ & $195 \pm 5$ & $64 \pm 2$ & $36 \pm 1$ & $<2$ & $<2$ & $0-500$ & $>500$ & $>500$ \\
\hline $\mathrm{Cu}$ & $450 \pm 10$ & $2700 \pm 19$ & $2160 \pm 15$ & $792 \pm 542$ & $128 \pm 3$ & $<2$ & $<2$ & $0-500$ & $>500$ & $>500$ \\
\hline $\mathrm{Ni}$ & $47 \pm 4$ & $55 \pm 1$ & $61 \pm 2$ & $40 \pm 6$ & $63 \pm 1$ & $<2$ & $<2$ & $0-30$ & $>30$ & $>30$ \\
\hline $\mathrm{Pb}$ & $890 \pm 34$ & $10200 \pm 68$ & $6750 \pm 81$ & $449 \pm 187$ & $11 \pm 2$ & $13 \pm 0$ & $11 \pm 3$ & $0-40$ & $>40$ & $>40$ \\
\hline $\mathrm{Zn}$ & $6870 \pm 416$ & $53100 \pm 1021$ & $59700 \pm 713$ & $2410 \pm 470$ & $52 \pm 5$ & $33 \pm 0$ & $36 \pm 1$ & $0-500$ & $>500$ & $>500$ \\
\hline \multicolumn{11}{|c|}{ Leaching $(\mu \mathrm{g} / \mathrm{l})$} \\
\hline As & $1240 \pm 122$ & $<20$ & $488 \pm 40$ & $22 \pm 2$ & $38 \pm 9$ & $<20$ & $<20$ & $0-8$ & $0-8$ & $8-50$ \\
\hline $\mathrm{Ba}$ & $2670 \pm 33$ & $257 \pm 19$ & $596 \pm 16$ & $13600 \pm 406$ & $<20$ & $<20$ & $<20$ & $0-300$ & $0-300$ & $300-4000$ \\
\hline $\mathrm{Cd}$ & $1460 \pm 106$ & $<20$ & $580 \pm 51$ & $<20$ & $<20$ & $<20$ & $<20$ & $0-2$ & $0-2$ & $2-40$ \\
\hline $\mathrm{Cr}$ & $11500 \pm 688$ & $3060 \pm 345$ & $1240 \pm 46$ & $265 \pm 9$ & $<20$ & $<20$ & $<20$ & $0-10$ & $0-10$ & $10-500$ \\
\hline $\mathrm{Cu}$ & $74 \pm 5$ & $<20$ & $80 \pm 7$ & $75 \pm 18$ & $<20$ & $33 \pm 3$ & $20 \pm 7$ & $0-45$ & $0-45$ & $45-2000$ \\
\hline $\mathrm{Mn}$ & $<20$ & $<20$ & $<20$ & $<20$ & $<20$ & $<20$ & $73 \pm 29$ & $0-150$ & $0-150$ & $150-1000$ \\
\hline $\mathrm{Na}\left(\cdot 10^{5}\right)$ & $418 \pm 4$ & $95 \pm 3$ & $222 \pm 4$ & $9.3 \pm 0.2$ & $0.03 \pm 0.001$ & $0.8 \pm 0.08$ & $0.3 \pm 0.03$ & $0-1$ & $0-1$ & $1-15$ \\
\hline $\mathrm{Ni}$ & $<20$ & $<20$ & $<20$ & $<20$ & $<20$ & $<20$ & $<20$ & $0-10$ & $0-10$ & $10-70$ \\
\hline $\mathrm{Pb}$ & $455 \pm 64$ & $30 \pm 15$ & $421 \pm 75$ & $2460 \pm 507$ & $<20$ & $<20$ & $69 \pm 40$ & $0-10$ & $0-10$ & $10-100$ \\
\hline $\mathrm{Zn}$ & $1070 \pm 190$ & $126 \pm 11$ & $257 \pm 76$ & $1710 \pm 174$ & $<20$ & $47 \pm 3$ & $252 \pm 102$ & $0-100$ & $0-100$ & $100-1500$ \\
\hline
\end{tabular}

Table 3. Total metal concentrations of the raw samples and leaching properties $(\mathrm{L} / \mathrm{S}=2)$ of the raw samples. Values are compared, Danish regulatory values (category 1-3) for construction purposes (Danish Ministry of the Environment (Miljøministeriet), 2015). 


\section{Discs}

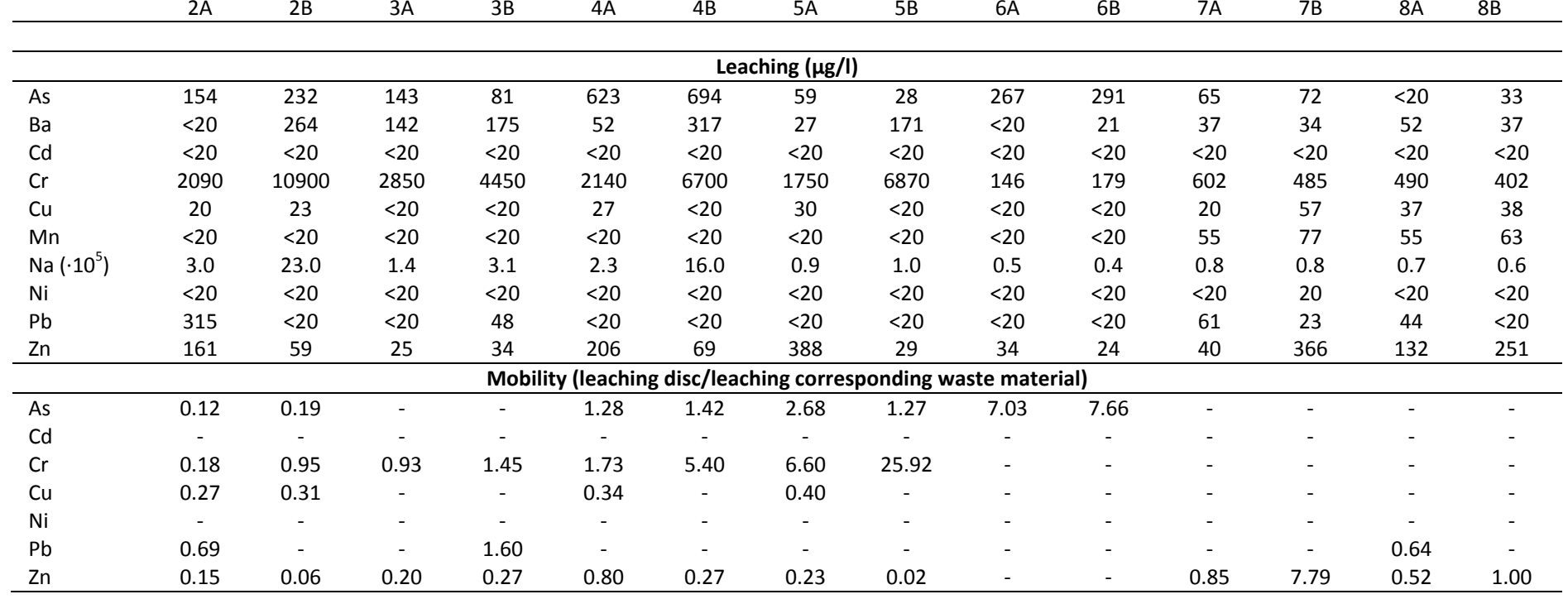

Table 4. Leaching properties $(\mathrm{L} / \mathrm{S}=2)$ of the disc samples and mobility of the metals in the dics normalized to the mobility of the corresponding waste material (- at least of the leaching values were below the detection limit) 


\begin{tabular}{cccc} 
Mixture name & $\mathrm{W}_{\mathrm{P}}(\%)$ & $\mathrm{W}_{\mathrm{L}}(\%)$ & $\mathrm{PI}$ \\
\hline 1 & 24.2 & 29.8 & 5.6 \\
2A & 24.2 & 30.0 & 5.8 \\
2B & 25.2 & 29.6 & 4.4 \\
3A & 31.1 & 36.3 & 5.2 \\
3B & 37.9 & 45.4 & 7.5 \\
4A & 34.0 & 43.6 & 9.6 \\
4B & 45.7 & 53.1 & 7.4 \\
5A & 25.3 & 29.1 & 3.8 \\
5B & 25.6 & 28.7 & 3.1 \\
6A & 20.2 & 24.2 & 4.0 \\
6B & 19.0 & 22.3 & 3.3 \\
7A & 23.6 & 29.6 & 6.0 \\
7B & 22.0 & 27.7 & 5.7 \\
8A & 19.7 & 25.6 & 5.9 \\
8B & 15.0 & 20.1 & 5.1 \\
\hline
\end{tabular}

Table 5. The plastic limit $\left(w_{P}\right)$, liquid limit $\left(w_{L}\right)$, and plasticity index $\left(P I\right.$, calculated as $\left.w_{L}-w_{P}\right)$ of the disc mixtures (before firing). 
Mixture name Initial water content Drying Shrinkage Firing Shrinkage

Appearance of fired discs

Vacuum water absorption (\%) Open porosity (\%) Dry density $\left(\mathrm{kg} / \mathrm{m}^{3}\right)$

\begin{tabular}{|c|c|c|c|c|c|c|c|}
\hline 1 & $15.8 \pm 1.1$ & $0.3 \pm 0.1$ & $0.5 \pm 0.1$ & Red & $23.3 \pm 0.2$ & $39.5 \pm 0.3$ & $1691 \pm 3$ \\
\hline $2 \mathrm{~A}$ & $14.9 \pm 1.5$ & $0.0 \pm 0.0$ & $0.1 \pm 0.3$ & $\begin{array}{l}\text { Red/yellow, spotted } \\
\text { appearance }\end{array}$ & $26.7 \pm 1.4$ & $42.1 \pm 1.3$ & $1578 \pm 34$ \\
\hline $2 B$ & $13.4 \pm 1.0$ & $0.2 \pm 0.1$ & $0.7 \pm 0.2$ & Yellow, few red spots & $32.2 \pm 1.5$ & $47.2 \pm 1.4$ & $1461 \pm 27$ \\
\hline $3 A$ & $15.2 \pm 1.1$ & $0.3 \pm 0.1$ & $-0.3 \pm 0.1$ & $\begin{array}{l}\text { Red/yellow, spotted } \\
\text { appearance }\end{array}$ & $29.6 \pm 0.4$ & $45.8 \pm 0.4$ & $1544 \pm 8$ \\
\hline $3 B$ & $17.2 \pm 2.2$ & $0.4 \pm 0.1$ & $-0.4 \pm 0.1$ & $\begin{array}{l}\text { Yellow, some red } \\
\text { spots }\end{array}$ & $34.4 \pm 0.7$ & $49.9 \pm 0.4$ & $1446 \pm 18$ \\
\hline $4 \mathrm{~A}$ & $15.6 \pm 1.0$ & $0.3 \pm 0.1$ & $-0.2 \pm 0.1$ & $\begin{array}{l}\text { Red/yellow, spotted } \\
\text { appearance }\end{array}$ & $32.9 \pm 1.1$ & $47.9 \pm 0.9$ & $1453 \pm 20$ \\
\hline $4 \mathrm{~B}$ & $16.5 \pm 1.6$ & $0.2 \pm 0.1$ & $0.1 \pm 0.1$ & $\begin{array}{c}\text { Yellow/red, spotted } \\
\text { appearance }\end{array}$ & $39.2 \pm 0.3$ & $51.5 \pm 1.2$ & $1313 \pm 22$ \\
\hline $5 A$ & $14.7 \pm 1.2$ & $0.3 \pm 0.2$ & $-0.1 \pm 0.1$ & Light red & $23.9 \pm 0.8$ & $39.9 \pm 1.0$ & $1669 \pm 21$ \\
\hline $5 B$ & $14.8 \pm 0.4$ & $0.3 \pm 0.1$ & $-0.2 \pm 0.0$ & Yellow/light red & $22.5 \pm 0.6$ & $38.4 \pm 0.9$ & $1708 \pm 8$ \\
\hline $6 \mathrm{~A}$ & $15.0 \pm 0.4$ & $0.3 \pm 0.1$ & $0.1 \pm 0.0$ & Red & $19.6 \pm 0.4$ & $35.5 \pm 0.8$ & $1808 \pm 5$ \\
\hline $6 B$ & $13.1 \pm 1.2$ & $0.1 \pm 0.2$ & $-0.6 \pm 0.1$ & Red & $18.0 \pm 0.6$ & $33.8 \pm 0.8$ & $1868 \pm 20$ \\
\hline $7 A$ & $15.4 \pm 0.5$ & $0.2 \pm 0.2$ & $0.9 \pm 0.1$ & Red & $21.5 \pm 0.9$ & $37.2 \pm 1.5$ & $1728 \pm 20$ \\
\hline 7B & $15.8 \pm 0.5$ & $0.1 \pm 0.1$ & $2.0 \pm 0.2$ & Dark red & $19.3 \pm 0.2$ & $34.6 \pm 0.3$ & $1789 \pm 21$ \\
\hline $8 \mathrm{~A}$ & $13.3 \pm 0.7$ & $0.6 \pm 0.1$ & $0.0 \pm 0.1$ & Red with black crystals & $18.7 \pm 1.1$ & $34.0 \pm 1.6$ & $1819 \pm 26$ \\
\hline $8 \mathrm{~B}$ & $13.6 \pm 0.9$ & $0.4 \pm 0.2$ & $0.5 \pm 0.4$ & $\begin{array}{c}\text { Dark red with black } \\
\text { crystals }\end{array}$ & $13.9 \pm 0.2$ & $27.9 \pm 0.2$ & $2007 \pm 10$ \\
\hline
\end{tabular}

Table 6. The initial water content (before drying and firing), shrinkage, appearance, vacuum water absorption, open porosity and dry density of the discs. 